\title{
C 110
}

保育所調理員の運動器症状に対する自動食器洗浄機導入の効果について

○ 小野雄一郎 ${ }^{1} 、$ 島岡みど门 ${ }^{2} 、$ 蛭田秀一 ${ }^{2} 、$ 今枝敏彦 ${ }^{3} 、$ 安藤詳子 ${ }^{4}$ 、堀文子 ${ }^{5} 、$ 巽あさみ ${ }^{6}$ 、山田宏 7 、鸨正吾 ${ }^{1} 、$ 吉田勉 ${ }^{1}$ 、谷脇弘茂 ${ }^{1}$ 、長岡芳 ${ }^{1}$ 、栗田秀樹 ${ }^{8}$ ( ${ }^{1}$ 藤田保衛大医公衛、 ${ }^{2}$ 名大保体センター、 ${ }^{3}$ 名大医衛生、 ${ }^{4}$ 名大医保健、

${ }^{5}$ 岐阜医短大、 ${ }^{6}$ 藤田保衛大衛生、 7 名大工佲呹示、 ${ }^{8}$ 藤田保衛大医衛生)

はじめに 保育所調理員について腰痛や頸肩腕障害等の運動器障害がこれまで報告されている。N市の公立 保育園にこの間自動食器洗浄機が導入されつつあるため、今回運動器症状に対する効果について検討した。 方法 対象はN市の公立保育園に勤務する調理員（女性のみ）で、93 年 5 月および 96 年 12 月の調查の両 方に参加した 196 名中、93 年時に食器洗浄機未導入職場に勤務し 96 年時には食器洗浄機がすでに導入され ていた職場に勤務する 82 名 (導入群)、および両年ともに食器洗浄機未導入職場に勤務する 104 名（非導入 群）を比較検討した。両群の概要を表 1 に示 した。運動器症状の調査のために、北山 （1985）に準じた 5 段階尺度（スコア：高 值ほど重症)の自覚症調査票を作成して用い た。スコアの統計的検討に当たり、異なる 2 群間については Wilcoxon two sample test、 同一の群内の経時的変化については Wilcoxon matched-pairs signed-rank test を用いた。結果 (1)93 年の時点では両群の スコアに有意な差は見出されなかったが、背 痛のみ導入群 (但し、この時点では洗浄機未 導入）に高い傾向があった $(\mathrm{p}=0.06)$ 。(2)96 年の時点では、導入群は非導入群に比心゙、

足・下肢痛および全般的体調が有意に良かった

(各 $\mathrm{p}=0.04,0.02$ )。背痛は両群ともほぼ同様 の值であった。(3)同一群内の経時的変化を見た 場合、導入群では、足・下肢痛が有意に改善し た（図 1)。また、症状スコアの増加傾向は明 瞭ではなかった。一方、非導入群では腕痛スコ アが有意に増加し、背痛も同様の傾向にあった。 他の症状スコアについてもやや増加する傾向 が見られた（図2）。考察とまとめ 食器洗浄 過程では作業者の手腕肩の反復動作による負 担や、立位拘束姿勢による躯幹・下肢への負担 が予測されるが、自動食器洗浄機の導入によっ てこれらが軽減されるものと期待された。今回、 経時的変化を見た場合に、非導入群では腕や背 の痛みをはじめ症状に悪化傾向が見られたが、 導入群では、足・下肢痛の改善が見られ、全般 的な症状の悪化傾向は見出されなかった。それ ゆえ、食器洗浄機の導入により運動器症状が改 善したり、悪化傾向が部分的に止められ得る可 能性が示唆された。また、非導入群の症状の増 悪に関して、作業要因や、季節、加齢等を考慮 した検討が必要と考えられた。

\section{(表1)対象.者の概要}

\begin{tabular}{|c|c|c|c|c|c|}
\hline & \multicolumn{4}{|c|}{ 自動食器洗浄機 } & \multirow{3}{*}{ p } \\
\hline & \multicolumn{2}{|c|}{ 道入群 $(n=82)$} & \multicolumn{2}{|c|}{ 非導入群 (n=104) } & \\
\hline & mean & sd & mean & sd & \\
\hline 年蔹 (歳) & 51.4 & 7.2 & 51.2 & 6.5 & $\overline{\mathrm{NS}}$ \\
\hline 職歴（年） & 17.5 & 6.9 & 16.9 & 7.2 & NS \\
\hline 身長 $(\mathrm{cm})$ & 153.4 & 5.3 & 152.8 & 5.6 & NS \\
\hline 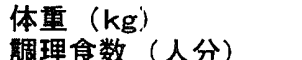 & 53.8 & 7.4 & 53.9 & 8.3 & NS \\
\hline 93年 & 102.5 & 13.1 & 86.8 & 24.9 & *** \\
\hline 96年 & 100.0 & 16.2 & 89.2 & 22.4 & ** \\
\hline 調理員数（人/職場） & & & & & \\
\hline 93年 & 2.6 & 0.6 & 2.3 & 0.5 & ** \\
\hline 96年 & 2.6 & 0.6 & 2.4 & 0.6 & * \\
\hline
\end{tabular}

年迷命、職歴、身長、体重の数值はすべて96年の調查時点のものを示した。



（因1）症状の变化

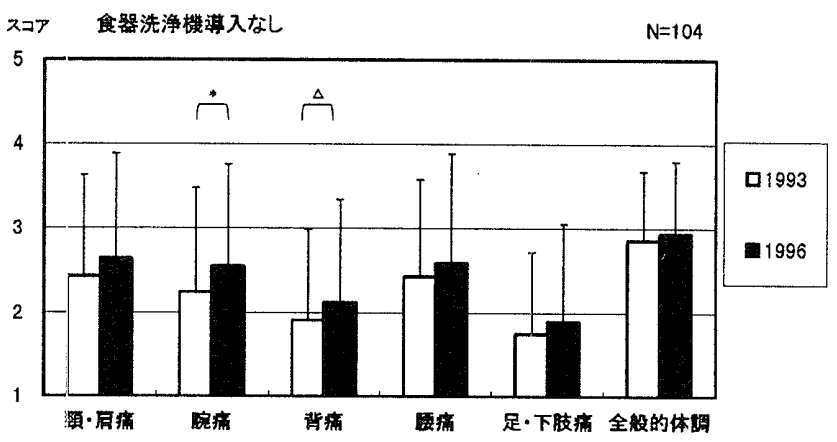

（图2）症状の变化 